виключали можливість рабовласництва. Усталені демократичні ідеали I. Петрункевича кристалізували його грунтовну візію щодо скасування кріпацького ладу. Іван Ілліч категорично відстоював «американську» модель аграрного сегменту економіки держави, засновану на дрібному фермерському виробництві.

\title{
Література:
}

1. Петрункевич И.И. Манифест 19 февраля в провинции (из личных воспоминаний). Речь. 1911. № 49. 19 февраля. С. 5.

2. Петрункевич И.И. Из записок общественного деятеля. Воспоминания . Прага: Б. и., 1934. 472 с.

3. Петрункевич И.И. Манифест 19 февраля в провинции (из личных воспоминаний). Речь. 1911. № 49. 19 февраля. С. 5.

4. Петрункевич И.И. Из записок общественного деятеля. Воспоминания . Прага: Б. и., 1934. 472 с.

5. Петрункевич И.И. Из записок общественного деятеля. Воспоминания . Прага: Б. и., 1934. 472 с.

6. Петрункевич И.И. К аграрному вопросу. М.: Типография О.Л. Сомовой, 1905. 35 с.

DOI https://doi.org/10.30525/978-9934-26-079-7-4

\section{МЕМОРІАЛЬНІ ВИМІРИ ДОНЕЦЬКА}

\section{Мартинчук I. I.}

кандидат історичних наук, доцент, доцент кафедри історії України та спеціальних галузей історичної науки

\section{Отземко О. В.}

кандидат історичних наук, дочент, доцент кафедри історії України та спеціальних галузей історичної науки

\section{Темірова Н. P.}

доктор історичних наук, професор, професор кафедри історії Украӥни та спеціальних галузей історичної науки Донецького національного університету імені Василя Стуса м. Вінниця, Украӥна

Меморіальні виміри, які «супроводжують» містян протягом їхнього щоденного життя, справляють помітний вплив на формування ідентичності, що особливо актуалізувалося на тлі окупації частини Донецької 
та Луганської областей, і зокрема, Донецька. 3 широко розмаїття «місць пам'яті» до уваги взято пам'ятники, герби, мемуари. Формування символічного простору Донецька великою мірою припало на радянську добу.

Монументально-меморіальний ландшафт міста станом на початок 2014 р. включав 193 об’єкти, 178 з яких споруджено за радянської доби, 15 - у роки незалежної України. Найбільше - 175 - з'явилися протягом 1940-1980-х pp. [8]. За тематичною ознакою найбільше пам'ятників присвячено «Великій Вітчизняній війні», воїнам-афганцям, радянським діячам, діячам культури (письменникам і поетам, науковцям). «Візитівкою» міста у радянський та порадянський період слугував монумент «Слава шахтерскому труду!», що являє собою скульптуру шахтаря у повний зріст, яким увага одразу приверталася до символу титульної професії Донеччини. У радянській традиції виконано монументи українським діячам - Т. Шевченку, I. Франку, Б. Хмельницькому. Тематичний набір монументальних «місць пам'яті» формував хибне уявлення, наче Донецьк не мав нерадянської історії, що не відповідає історичній дійсності.

У роки незалежності України пам'ятниковий ландшафт міста поповнювався новими об'єктами. На відміну від решти України, де місцеві еліти, загалом поділяючи регіональні історичні оцінки, перебували під помітним впливом столиці, у східних областях місцева влада у площині колективної пам'яті демонструвала вищий рівень автономності по відношенню до центру. Про це свідчить той факт, що у Донецьку протягом 1990-х -2000-х рр. поряд з монументами жертвам політичних репресій, жертвам Голокосту, було зведено монументи загиблим міліціонерам, воїнам-інтернаціоналістам, герою-рятівнику, ліквідаторам Чорнобильської катастрофи тощо. Серед увічнених персоналій бачимо Героїв Радянського Союзу Ф. Толбухіна, М. Ватутіна, засновника Донецького металургійного заводу Дж. Юза та інших. У центральній частині міста встановлено два прижиттєві пам'ятники - С. Бубці, українському легкоатлету, чемпіону Європи та світу у стрибках із жердиною, Герою України, та російському співаку Й. Кобзону, вихідцю $з$ Донеччини. Принципова відмінність меморіального простору - у тотальному збереженні радянських пам'ятників i пролонгуванні радянської меморіальної традиції на зламі XX - XXI ст. Така меморіальна політика спрямовувалася на формування специфічної ідентичності, що укладалася у поняття місцевого, «донецького» патріотизму, який цілеспрямовано протиставлявся українському проєкту.

Герб - це офіційна емблема, в якій відображаються історія та традиції народу, найбільш характерні риси населеного пункту. Комплекс гербів міст Донецької області є невід'ємною частиною радянської геральдики. Вибір гербів міст Донецької області із середини 1960-х рр. 
зі стихійного процесу перетворюється на ретельно спрямований i набирає значних обертів. Найбільш активний етап відноситься до кінця 1960-х - середині 1980-х рр. Створення проектів не одразу вело до офіційного затвердження гербів, деякі з них були широко розтиражовані, а затверджені лише декілька років потому.

Герб Донецька - офіційний геральдичний символ міста. На сьогодні місто має два герби - Великий і Малий. Перший, що має назву «Малий герб», був затверджений 1968 р. Другий герб був прийнятий у 1995 р. [4, арк. 268-269; 70; 162].

У більшості гербів Донецької області було присутніми зображення териконів. Їх символізм у радянський час вбачався у тому, що вони $\epsilon$ найбільш наочним втіленням титанічних зусиль, які вимагає праця шахтаря. У радянський час відбулось перекодування попереднього негативного сприйняття «вугільних земель» [7, с. 56]. Загалом в описі гербів при розкритті символіки наголошувалося перш за все на роль, яку місто відігравало в господарському комплексі, підкреслювалося відтворення ідей «комуністичного будівництва».

Художньо-естетична й емоційна складові гербів підсилюються додатковими компонентами. Майже половина затверджених гербів оздоблені стрічками чи написами 3 назвами областей, районів, міст, кожен десятий має уточнювальний елемент - дату їхнього заснування чи утворення, оригінальні гасла або девізи [6]. Таким чином, відбувалась уніфікація символів і вихолощувалися національні особливості, підкреслювався регіональний компонент. Ще однією особливістю емблем міст Донецької області було ігнорування історичної геральдичної спадщини та власне історії. Герби повинні були утверджувати радянський міф, оспівувати героїчну працю, створення нової людини.

Мемуаристика, яка відбиває період в історії Донецька (на той час Юзівки) від 1869 до 1917 рр., різноманітна за авторським складом і часом походження. Це спогади інженерів, які працювали на Юзівському заводі та навколишніх копальнях: А. Ауербаха (видані у 1909 р.), О. Фєніна (створені в еміграціі), І. Бардіна (написані у радянські повоєнні роки) $[1 ; 2 ; 9]$. Певну інформацію про Юзівку початку XX ст. можна почерпнути зі спогадів, які в різні роки писали «ветерани комуністичної партії», згадуючи свою робочу молодість. Значну частину населення Юзівки становили ремісники, дрібні підприємці, працівники сфери торгівлі і послуг, вчителі, лікарі тощо. Тому цікавими $є$ спогади А. Залмана - представника єврейської громади, лікаря-студента, в майбутньому відомого письменника, В. Вересаєва [3]. Своєрідний погляд на Юзівку віддзеркалюють записки іноземців, які за різних обставин відвідували або жили у Юзівці: журналістів-мандрівників Г. Нормана, Л.Вілларі, підприємця Дж. Юма $[10 ; 12 ; 13]$, вчительки англійської мови дітей Артура Юза Ені Гвен Джонс [11]. 
Кожен автор мемуарів «конструює» свою Юзівку. Інженери багато уваги приділяють технічним деталям виробництва, робітники згадують важку працю з дитячих років. Англійські мандрівники наголошують на визначальній ролі іноземного (англійського) підприємництва в розвитку російської промисловості, буквально малюючи картину «нічого не було - виросло квітуче місто». Мешканець заводського передмістя докладно описує його вулиці, лавки, крамниці, базар і т. і., молода англійська вчителька - розваги. Утім, фрагментарність і розмаїття поглядів та оцінок не заважає побачити швидку еволюцію селища при заводі, яке набуває рис промислового міста, етнічне і соціальне розмаїття населення, кожен з елементів якого робить свій внесок у розвиток Юзівки, поєднання швидкої промислової модернізації та гострих соціальних проблем.

Отже, меморіальний вимір сучасного Донецька має виразне радянське походження, що у роки Незалежності України місцевою елітою використовувалося для формування особливої регіональної ідентичності.

\section{Література:}

1. Ауэрбах А. Воспоминания о начале развития каменноугольной промышленности в России. Русская старина.1909, июнь. C. $451-472$.

2. Бардин И. Жизнь инженера. URL: https://www.booksite.ru/ fulltext/bar_1/index.htm.

3. Вересаев В. Воспоминания. 2. В студенческие годы. (1935). URL: http://az.lib.ru/w/weresaew_w_w/text_0290.shtml

4. Державний архів Донецької області (ДАДО), ф. Р-2794, оп. 2, спр. 191, арк. 268-269; ф. Р-279, оп. 4, спр. 190, арк. 70; спр. 192, арк. 162.

5. Иващенко А. История еврейской общины Донецка. Донецк, 2014.160 с.

6. Нескоромний О. Місцева символіка єднає Україну. Віче. № 15, URL: http://veche.kiev.ua/journal/4849/ (Доступ серпень 2015).

7. Праця, виснаження та успіх: промислові мономіста Донбасу / М. Ільченко та ін.; за ред., В. Кулікова і І. Склокіної. Львів, 2018, 244 с.

8. Реєстр культурного надбання Донецької області (пам'ятки історії та культури). URL: https://wikimediaukraine.files.wordpress.com> 2012/06) donetsk-register (Доступ 25 серпня 2019).

9. Фенин А. Воспоминания инженера: К истории общественного и хозяйственного развития России (1883-1906 гг.). Прага: Рус.инст., 1938. $200 \mathrm{c}$.

10. Hume G. Thirty-Five Years in Russia. London: Simpkin, 1914. 320 p. 
11. Jones Annie Gwen. Life on the Steppes of Russia 1889 to 1892. URL: https://www.garethjones.org/margaret_siriol_colley/annie\%20gwen/ life-steppes.htm.

12. Norman H. All the Russians: Travels and Studies in Contemporary European Russia, Finland, Siberia, the Caucasus, and Central Asia. New York, 1904. 476 p.

13. Villari L. Russia under the Great Shadow. London: T.F. Unwin, 1905. 330 p.

DOI https://doi.org/10.30525/978-9934-26-079-7-5

\title{
ФАКТ ЗАХОПЛЕННЯ У ПОЛОН КОМАНДУВАЧА 6-Ї АРМІЇ I. М. МУЗИЧЕНКА У СЕРПНІ 1941 РОКУ: ІСТОРИКО-ДЖЕРЕЛОЗНАВЧИЙ ЗРІЗ
}

\author{
Москальчук К. В. \\ аспірантка кафедри всесвітньої історії \\ Центральноукраӥнського державного педагогічного університету \\ імені Володимира Винниченка \\ м. Кропивницький, Украӥна
}

У серпні 1941 року в лісовому урочищі «Зелена Брама» внаслідок німецького оточення загинули 6-та і 12-та радянські армії, а обидва командувачі армій потрапили у полон. У сучасній історіографії події отримали назву «Уманський котел», а їхня історія до сьогоднішнього дня залишається актуальною і малодослідженою.

6 серпня 1941 року в районі с. Сухий Ташлик німці знищили залишки так званої «колони особливого призначення», у складі якої командувач 6-ї армії намагався прорватися 3 оточення [7]. Командарм-6 без противу був захоплений у полон бійцями 101-ї легко-піхотної німецької дивізії [6, с. 129]. У радянській історичній науці стосовно цього існувала теза, що І. М. Музиченко потрапив у полон тому, що був тяжко поранений. Саме так описувався факт захоплення командування 6-ї армії у більшості радянських публікацій присвячених початковому етапу німецько-радянської війни. Згодом ця інформація «перекочувала» $\mathrm{i}$ в сучасні дослідження. Про тяжке поранення, внаслідок якого I. М. Музиченко втратив ногу, писав у своїх спогадах член Військової ради Південно-Західного напрямку М. С. Хрущов [11, с. 253]. Очевидець подій Є. А. Долматовський також наголошував на поранені командувача 6-ї армії [4, с. 79]. У деяких післявоєнних нагородних документах вказано, що I. М. Музиченко потрапив у полон внаслідок 